\title{
Relaxant effect of BAY 4I-2272 in the rabbit isolated detrusor smooth muscle (DSM): involvement of cGMP-independent mechanisms
}

\author{
Fernando R Báu*, Cleber E Teixeira, Gilberto De Nucci and Edson Antunes
}

Address: Department of Pharmacology, Faculty of Medical Sciences, UNICAMP, Campinas, SP, Brazil

Email: Fernando R Báu* - fernandorbau@gmail.com

* Corresponding author

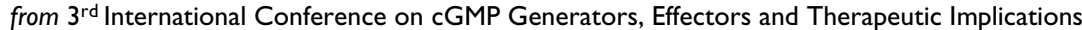 \\ Dresden, Germany. I5-17 June 2007 \\ Published: 25 July 2007 \\ BMC Pharmacology 2007, 7(Suppl I):P4 doi:I0.II86/I47|-22I0-7-SI-P4
}

This abstract is available from: http://www.biomedcentral.com/I47I-22I0/7/SI/P4

(C) 2007 Báu et al; licensee BioMed Central Ltd.

\section{Background}

Overactive bladder $(\mathrm{OAB})$ is described as urgency with or without incontinence, usually accompanied by frequency and nocturia. Overactive bladder reflects involuntary DSM as a consequence of enhanced cholinergic-mediated contractions and decreased b-adrenoceptor-mediated relaxations. The nitric oxide (NO)-cyclic GMP signaling pathway has been described to modulate the muscular tone, neurotransmission and blood flow in DSM, but the exact role of NO in the bladder is not completely understood. It is accepted that NO deficiency contributes to triggering $\mathrm{OAB}$. The compound BAY 41-2272 has been described as a drug that directly activates the soluble guanylate cyclase leading to NO-independent cGMP accumulation. BAY 41-2272 produces potent relaxations in vascular and non-vascular smooth muscle tissues by cGMP-dependent and independent mechanisms, but no studies have been carried out with DSM.

\section{Purpose}

The aim of this study was to evaluate the relaxant effect of BAY 41-2272 in the rabbit isolated bladder and the mechanisms underlying the relaxant responses.

\section{Methods}

The present study was approved by the Ethics Committee for Experimental Research of the State University of Campinas (UNICAMP). Male New Zealand White rabbits (3 kg) were anaesthetized with urethane ( $1 \mathrm{~g} / \mathrm{kg}$, i.v.) After exsanguination, the abdomen was opened and the bladder was removed and placed in Krebs solution. The DSM strips $(2 \times 4 \times 10 \mathrm{~mm})$ were suspended between two metal hooks and mounted in $10 \mathrm{ml}$ organ baths containing with Krebs' solution at $37^{\circ} \mathrm{C}, \mathrm{pH} 7.4$, and aerated continuously with $95 \% \mathrm{O}_{2}$ and $5 \% \mathrm{CO}_{2}$. The development of isometric tension was registered using force transducers connected to a PowerLab $400^{\mathrm{TM}}$ data-acquisition system (ADInstruments, MA, USA). Tissue preparations were equilibrated for $1 \mathrm{~h}$ before the start of the experiments. Initially, DSM preparations were challenged with $80 \mathrm{mM} \mathrm{KCl}$ to confirm tissue viability. Concentration-response curves for BAY 41-2272 $(0.001-10 \mu \mathrm{M})$ were contructed in the presence and in the absence of L-NAME $(100 \mu \mathrm{M})$, ODQ $(10 \mu \mathrm{M})$ or sildenafil $(0.1 \mu \mathrm{M})$ The relaxations were plotted as percentages of the contraction induced by carbachol (10 $\mu \mathrm{M})$. Concentration-response curves to sodium nitroprusside (SNP, 0.01-10 $\mu \mathrm{M}$ ) and gliceryl trinitate (GTN, 0.01$10 \mu \mathrm{M}$ ) were also constructed.

\section{Results}

BAY 41-2272 produced a concentration-response curve (Fig. 1a) in isolated DSM with a potency $\left(\mathrm{pEC}_{50}\right)$ and maximal response $\left(\mathrm{E}_{\max }\right)$ of $6.71 \pm 0.13$ and $134.97 \pm$ 4.84 , respectively. The $\mathrm{pEC}_{50}$ values for BAY 41-2272 were higher than for SNP $(6.04 \pm 0.15)$, but not statistically different from GTN $(6.37 \pm 0.21)$. The $\mathrm{E}_{\max }$ values for BAY were signicantly higher $(\mathrm{p}<0.001)$ than those for SNP $(48.87 \pm 3.62)$ and GTN $41.94 \pm 4.10$. 
a

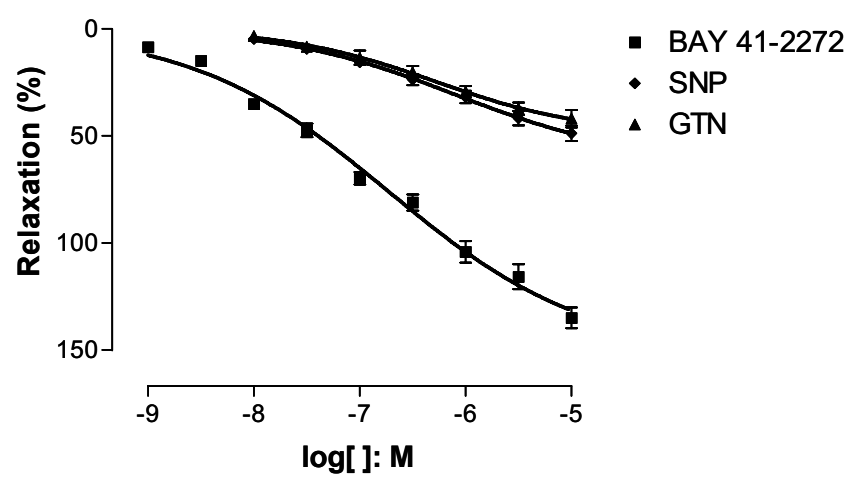

b

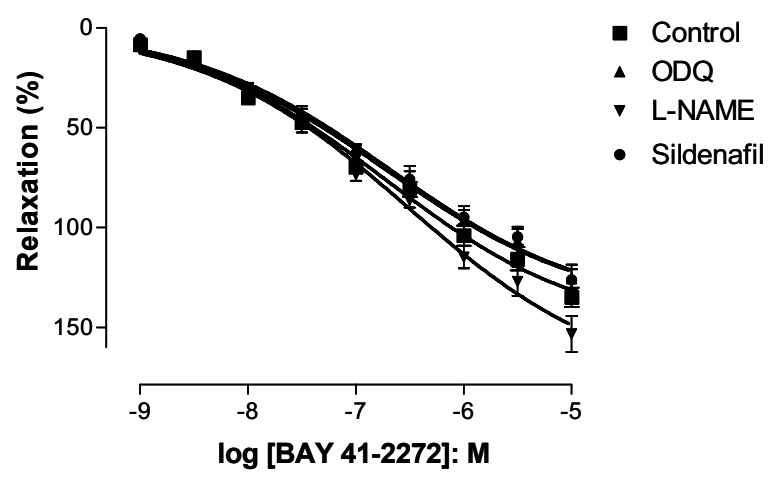

\section{Figure I}

Relaxant effects of BAY 4I-2272, sodium nitroprusside (SNP) and glyceryl trinitrate (GTN) (Panel A) and effect of L-NAME, ODQ and sildenafil in the BAY 4I-2272 induced-responses (Panel B) in the rabbit isolated detrusor smooth muscle.

The potency of BAY 41-2272 was not significantly altered in the presence of L-NAME $(6.37 \pm 0.33)$, ODQ $(6.66 \pm$ $0.15)$ or sildenafil $(6.67 \pm 0.20)$ in comparison with vehicle $(6.72 \pm 0.12)$. Similarly the $\mathrm{E}_{\max }$ values were not altered in the presence of L-NAME $(153.30 \pm 9.02)$, ODQ $(125.69 \pm 7.06)$ and sildenafil $(126.18 \pm 5.14)$ compared with vehicle $(134.97 \pm 4.84)$ (Fig. 1b).

\section{Conclusion}

In contrast with NO donors, BAY 41-2272 causes a complete relaxation of rabbit DSM. Our findings that relaxant responses to BAY 41-2272 are unaltered by L-NAME, ODQ and sildenafil indicate that BAY 41-2272 acts in an cGMP-independent manner to produce DSM relaxations. Therefore, BAY 41-2272 constitutes a drug with great potential to treat overactive bladder.
Publish with Biomed Central and every scientist can read your work free of charge

"BioMed Central will be the most significant development for disseminating the results of biomedical research in our lifetime. " Sir Paul Nurse, Cancer Research UK

Your research papers will be:

- available free of charge to the entire biomedical community

- peer reviewed and published immediately upon acceptance

- cited in PubMed and archived on PubMed Central

- yours - you keep the copyright

Submit your manuscript here:

http://www.biomedcentral.com/info/publishing_adv.asp
BioMedcentral 